Jurnal Riset Biologi dan Aplikasinya, Volume 3, Issue 2, September 2021

Jurnal Riset Biologi dan Aplikasinya

\title{
Diversity of Lepidoptera: Rhopalocera at Selorejo Waterfall Area, Ponorogo District, East Java, Indonesia
}

\author{
Siti Zulaikha*, M. Azmi Dwi Susanto \\ Biology Departement, Faculty Science and Technologi, UIN Sunan Ampel Surabaya \\ Jln. Ahmad Yani No. 117, Jemur Wonosari, Wonocolo District, Surabaya 60237, East Java, Indonesia \\ *Corresponding Author: \\ e-mail: zulaikasit456@gmail.com
}

\section{Article History \\ Received : 5 June 2021 \\ Revised : 2 July 2021 \\ Approved : 1 September 2021 \\ Published : 30 September 2021}

\section{Keywords}

diversity; lepidoptera; butterflies, Selorejo waterfall

\begin{abstract}
Selorejo Waterfall is a natural tourist area that is directly adjacent to the Sigogor Mountain Nature Reserve and has a beautiful and natural environment. This makes the Selorejo Waterfall area has a good environment for the sustainability of various species of butterflies. This research aimed to find out the diversity and abundance of butterflies in the Selorejo Waterfall area. This research was conducted using the Visual Day Flaying method by following the trail in the Selorejo Waterfall area. This study found 26 species belongs 4 families with 109 individuals in total. The value of the species diversity index at the location of $\mathrm{H}^{\prime}=2.81$ moderate category. The diversity of butterflies in the Selorejo Waterfall area was influenced by the availability of host plants and feed as well as abiotic factors.
\end{abstract}

How to cite: Zulaikha, S., \& Susanto, M. A.D. (2021). Diversity of Lepidoptera: Rhopalocera at Selorejo Waterfall Area, Ponorogo District, East Java, Indonesia. Jurnal Riset Biologi dan Aplikasinya, 3(2): 68-72. DOI: 10.26740/jrba.v3n2.p68-72.

\section{INTRODUCTION}

Butterflies are one of the flying insects in the Order of Lepidoptera with the characteristics of insects there are scales on their wings with variations, patterns, interesting colors (Lestari et al., 2015). The body consists of 3 parts, namely the head (cephal), chest (thoracic) and abdomen. One of the roles of butterflies in an ecosystem is as pollinators. Therefore, the existence of various species of butterflies in a location is very helpful in the process of pollination of plants (Setiawan et al., 2018). Thus, butterflies can be one of the important factors in maintaining the balance of the ecosystem at a location (Alfidah et al., 2016).

The existence and diversity of butterfly species in a location can be used as a bioindicator of environmental quality. Land transfer can lead to a decrease in environmental quality due to the diversity of butterflies losing habitat and host plants and feed that will support their life cycle (Adi et al., 2017). In an area that still has a high plant diversity will potentially be a habitat for various species of butterflies, this is because butterflies will choose habitats with a sufficient amount of feed material for their survival (Rahayuningsih et al., 2012).

Selorejo waterfall is a natural tourist area in Ngebel District, with a distance of $35 \mathrm{~km}$ from the center of Ponorogo City which has a beautiful and natural environment, due to its location far from the city, and directly adjacent to the Sigogor Mountain Nature Reserve area. There is no scientific research related to the potential of natural resources and the diversity of insects, especially butterflies in Selorejo waterfall. This allows the term The Lost Treasure, which is the loss of a potential without being known and without any conservation efforts. Therefore, by conducting this research, data will be obtained regarding biodiversity, especially butterflies as a first step in conservation, so that later appropriate conservation actions can be taken to maintain the preservation of biological butterflies in Selorejo waterfall area to be the right habitat for the survival of butterflies. This research aimed to analyze the 
diversity of species and abundance of butterflies in the Selorejo waterfall tourist area.

\section{MATERIALS AND METHODS}

Time and Location Study

The study was conducted in January February 2021 on the active hours of butterflies (08.00 am - $01.00 \quad \mathrm{pm})$. This research was conducted in the Selorejo waterfall area of Toyomerto Hamlet, Pupus village, Ngebel district, Ponorogo Regency,

East Java (7046’27.0”S, $\left.111^{\circ} 40^{\prime} 40.11^{\prime \prime} \mathrm{E}\right)$.

\section{Sampling Procedure}

The tools used during the study are stationary, watches, insect net, GPS (Global Positioning System) to determine the point of the study location, Light Meters to measure light intensity and thermo-higrometers to measure the temperature and humidity of the environment. The study was conducted at one location along the Selorejo Waterfall stream in combination with Visual Day Flaying by noting the species and number of individuals. The study also recorded abiotic factors, namely temperature $\left({ }^{\circ} \mathrm{C}\right)$, humidity (\%) and light intensity (lx). Butterflies were identified using some references (Mustari \& Gunadharma, 2016; Baskoro et al., 2018 and Ilhamdi et al., 2018).

\section{Data Analysis}

The butterfly data obtained in the sudy will be analyzed using the Shannon-Wienner diversity index $\left(H^{\prime}\right)$ (Nuraini et al., 2020) and Relative Abundance (RA) (Ilhamdi et al., 2019) with the following formula:

Diversity Index

$$
H^{\prime}=\sum\left(\frac{n i}{N} \operatorname{In} \frac{n i}{N}\right)
$$

Relative abundance Index

$$
R A=n i / N x 100 \%
$$

Note:

$\mathrm{H}^{\prime}=$ Diversity index

$\mathrm{RA}=$ Relative abundance index

$n i=$ Number of individual species- $\mathrm{i}$

$N=$ Total number of individuals

\section{RESULTS AND DISCUSSION}

Based on the results of identification carried out by butterfly species found in the Selorejo waterfall area of Ponorogo regency, 4 families from 26 species with 109 individuals (Table 1).

The results of the analysis of ShannonWiener's diversity index in the Selorejo waterfall area of Ponorogo Regency have a value of $\mathrm{H}^{\prime}=$ 2.81 , so it can be known that the diversity of butterflies in the Selorejo waterfall area is in the moderate category. This shows that the Selorejo waterfall area has a fairly good habitat for the survival of various species of butterflies. The value of the butterfly diversity index in the Selorejo waterfall area is smaller than the butterfly diversity value in the Taman Kehati Unnes $\mathrm{H}^{\prime}=3.72$ (Priyono \& Abdullah, 2013). While the value of the butterfly diversity index in the Selorejo falls area is greater than the butterfly diversity index in the Mandor Nature Reserve with a value of $\mathrm{H}=1.7$ (Florida et al., 2015).

The value of diversity index in a region is influenced by the availability of feed plants, in addition butterfly diversity is also influenced by abiotic factors consisting of temperature, humidity and light intensity (Ilhamdi et al., 2019). So, if biotic and abiotic factors in an area are adequate, it will be directly proportional to the diversity of butterflies in a location.

The temperature in the Selorejo waterfall area worth $28.4^{\circ} \mathrm{C}$ and the environmental humidity value of $74.6 \%$ (Table 2) belongs to the category that is good for the survival of butterflies, this is because butterflies are poikilothermic organisms and require a warm environmental temperature for the metabolic system to run properly (Ashari et al., 2019) and will affect its life activities. The temperature and humidity of the environment in the Selorejo waterfall area is related to the high intensity of light entering the environment. This is because the Selorejo waterfall area has a little canopy cover and trees at some point. Therefore, the canopy is a constituent component of an ecosystem in order to regulate temperature and humidity into a suitable habitat for butterflies.

The composition of the family is known that the family Nymphalidae has the most abundant found during the study with a value of $35.7 \%$ (Figure 1). The large number of families Nymphalidae because it is known as the most abundant group of butterflies in the Rhopalocera sub-Order and has more than one host plant and feed (polyfag). In addition, the family Nympahlidae is a group of butterflies with a good level of adaptation to the environment so it is very easy to find in nature (Borror et al., 2005). 
Table 1. Rhopalocera's Diversity and Relative Abundance at Selorejo waterfall

\begin{tabular}{|c|c|c|c|}
\hline Family & Species & Individual & $\begin{array}{l}\text { Relative } \\
\text { abundance }\end{array}$ \\
\hline \multirow{6}{*}{ Papilionidae } & Papilio memnon & 3 & 14.68 \\
\hline & Troides helena & 2 & 2.75 \\
\hline & Troides amphrysus & 1 & 0.92 \\
\hline & Graphium agamemnon & 2 & 1.83 \\
\hline & Graphium sarpedon & 2 & 1.83 \\
\hline & Graphium doson & 7 & 6.42 \\
\hline \multirow[t]{12}{*}{ Nymphalidae } & Lethe confusa & 7 & 6.42 \\
\hline & Danaus genutia & 7 & 6.42 \\
\hline & Hypolimnas bolina & 2 & 1.83 \\
\hline & Neptis hylas & 5 & 4.59 \\
\hline & Euploea mulciber & 1 & 0.92 \\
\hline & Ypthima baldus & 3 & 2.75 \\
\hline & $\stackrel{1}{Y}$ pthima pandocus & 1 & 0.92 \\
\hline & Junonia hedonia & 2 & 1.83 \\
\hline & Junonia iphita & 1 & 0.92 \\
\hline & Mycalesis sp. & 2 & 1.83 \\
\hline & Parantica aspasia & 1 & 0.92 \\
\hline & Symberenthia lilaea & 3 & 2.75 \\
\hline \multirow[t]{4}{*}{ Pieridae } & Eurema hecabe & 22 & 20.18 \\
\hline & Catopsilia pomona & 1 & 0.92 \\
\hline & Delias belisama & 2 & 1.83 \\
\hline & Letopsia nina & 4 & 3.67 \\
\hline \multirow[t]{4}{*}{ Lycaenidae } & Pitecops sp. & 2 & 1.83 \\
\hline & Heliophorus epicles & 1 & 0.92 \\
\hline & Coleta rhode & 4 & 3.67 \\
\hline & Jamides sp. & 7 & 6.42 \\
\hline Total & & 109 & 100 \\
\hline
\end{tabular}

Table 2. Abiotic factors in Selorejo waterfall area

\begin{tabular}{ccc}
\hline No & Abiotic factors & Value \\
\hline 1 & Temperature & $28.4^{\circ} \mathrm{C}$ \\
2 & Humidity & $74.6 \%$ \\
3 & Light Intensity & $23733 \mathrm{~lx}$ \\
\hline
\end{tabular}

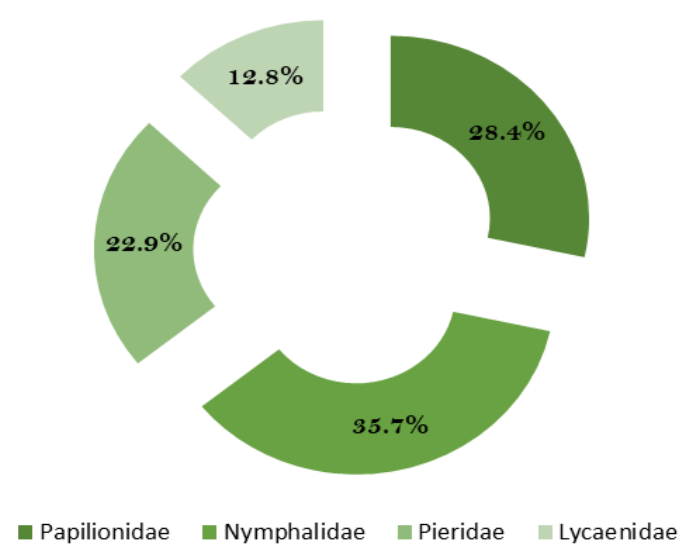

Figure 1. Rhopalocera family in Selorejo waterfall area 
The family Nymphalidae has the characteristic of having white, black and orange wings and has variety of wings color patterns (Baskoro et al., 2018). The family Nymphalidae has a moderate reduced wing front limb, and a front wing shape that forms an angle. In addition, Nymphalidae are cosmopolitics butterflies that are widespread and prefer open areas (Rohman et al., 2019).

Based on the analysis of the Relative Abundance index in the region Eurema hecabe (Figure 1) has the highest value $\mathrm{AR}=20.18$ with 22 individuals. Eurema hecabe is a species in the family Pieridae with low flying ability and agile motion. Eurema hecabe has thoracic, abdomen and basic color of yellow-clothed wings with black patches on the elbowing upper wing plot. In addition, Eurema hecabe has black patches on the bottom of its wings (Baskoro et al., 2018).

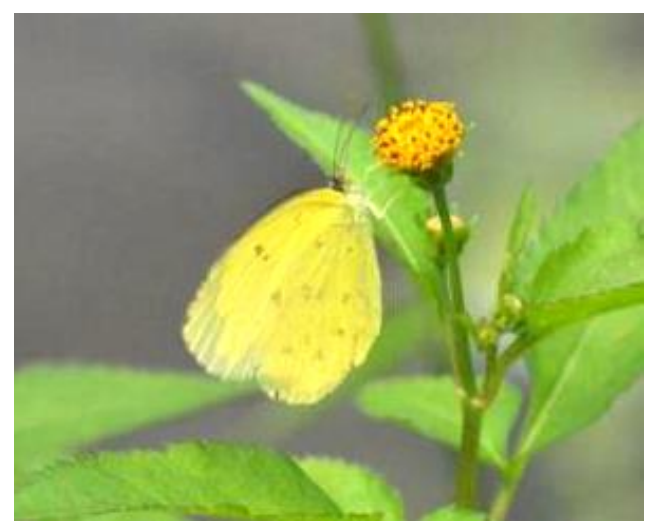

Figure 2. Eurema hecabe

Selorejo waterfall area has open environmental conditions; there are many lower and medium layer plants with trees at some point. During the study Eurema hecabe many were found to be doing nectaring on the Bidens pilosa plant (family Asteraceae) to meet its nutritional sources and bask on rocks close to the flow of water. The amount of feed plants of this species of Bidens pilosa is very much found in the Selorejo waterfall area, hence it is directly proportional to the abundance of the species of Eurema hecabe. According to Ilhamdi et al. (2018) states that Eurema hecabe is one species that can be found in snuffed out with abundant grasslands and shrubs. Mustari \& Gunadharma (2016) also added that Eurema hecabe is a species that likes an open environment and sufficient sunlight. This shows that supportive environmental conditions cause Eurema hecabe species to be widely encountered during research.

\section{CONCLUSSION}

Based on research conducted it was known that the diversity of butterflies in the Selorejo Waterfall was in moderate category, consisted of 26 species belongs to 4 families. The most common family found in the study was Nymphalidae at $35.7 \%$. While the result of the relative abundance of Eurema hecabe has a value of $\mathrm{RA}=20.18$ with 22 individual numbers.

\section{REFERENCES}

Alfida, Hanum, U., \& Eliyanti. (2016). Kupu-Kupu (Rhopalocera) Di Kawasan Hutan Kota Bni Banda Aceh. Jurnal Biotik, 4 (2), 117-127. DOI: http://dx.doi.org/10.22373/biotik.v4i2.2906

Ashari, F.N., Addiniyah, N.R., \& Airni, H.A. (2019). Inventory Of Diversity Butterflies (Lepidoptera: Rhopalocera) in Sumber Clangap and Waduk Selorejo In East Java. Biota: bio \& pend bio. 12(1): 32-37. DOI: https://doi.org/10.20414/jb.v12i1.1

Baskoro, K., Kamaludin, N., \& Irawan, F. (2018). Lepidoptera Semarang Raya. Semarang: Departemen Biologi Universitas Diponegoro.

Borror, D.J., C., A. Triplehorn \& Johnson. (2005). Introduction to Study of Insects $7^{\text {th }}$ Edition. C.A, U.S.A: Brooks/Cole, Belmont.

Florida, M., Setyawati, Tri, R., \& Yanti, Ari, H. (2015). Inventarisasi Jenis Kupu-kupu pada Hutan Kerangas di Kawasan Cagar Alam Mandor Kabupaten Landak. Jurnal Probiont. 4(1), 260265.

DOI:

http://dx.doi.org/10.26418/probiont.v4i1.9794.

Ilhamdi, M. Liwa., Al Indrus, A \& Santosa, D. (2018). Kupukupu Taman Wisata Suranadi. Lombok Barat: Arga Puji Press.

Ilhamdi, M. Liwa., Al Indrus, A \& Santoso, D. (2019). Struktur Komunitas Kupu-Kupu Di Taman

Wisata Alam Suranadi, Lombok Barat. Jurnal Biologi Tropis. 19(1), 147-153. DOI:

http://dx.doi.org/10.29303/jbt.v 19i2.880

Kurniawan, B., Apriani, R., \& Cahayu, S. (2020). Keanekaragaman Spesies Kupu-Kupu (Lepidoptera) Pada Habitat Eko-Wisata Taman Bunga Merangin Garden Bangko Jambi. AlHayat: Journal of Biology and Applied Biology. 3(1), $1-7$.

DOI:

http://dx.doi.org/10.21580/ah.v3i1.6064

Lestari, D.F., Rizma, D.A.P., Ridman, M, Purwaningsih, A.D. (2015). Diversity of Butterflies (Insects: Lepidoptera) in Alas Bromo, Karanganyar, 
72 | Zulaikha \& Susanto; Diversity of Lepidoptera: Rhopalocera at Selorejo Waterfall

Central Java. Pros Sem Nas Masy Biodiv Indonesia, $1 \quad$ (6), 1284-1288. DOI: https://doi.org/10.13057/psnmbi/m010604

Mustari, A.H \& Gunadharma, N. (2016). Kampus Biodiversitas: Kupu-kupu di Wilayah Kampus IPB Dramaga. Bogor: IPB Press.

Nuraini, U., Widhiono., I \& Riwidiharso, E. (2020). Keanekaragaman dan Kelimpahan Kupu-Kupu (Lepidoptera: Rhopalocera) di Cagar Alam Bantarbolang, Jawa Tengah. BioEksakta: Jurnal Ilmiah Biologi Unsoed. 2(2), 157-164. DOI: https://doi.org/10.20884/1.bioe.2020.2.2.1756

Priyono, B \& Abdullah, M. (2013). Keanekaragaman Jenis Kupu-Kupu Di Taman Kehati Unnes. Biosaintifika. $\quad 5(2), \quad$ 101-105. DOI: https://doi.org/10.15294/biosaintifika.v5i2.2749
Rahayuningsih, M \& Oqtafiana, R \& Priyono, B. (2012). Keanekaragamn Jenis Kupu-Kupu Superfamili Papilionidae Di Dukuh Banyuwindu Desa Limbangan Kecamatan Limbangan Kabupaten Kendal. Jurnal MIPA. 35(1),12-20.

Rohman, F., Efendi, M.A., \& Andriani, L.R. (2019). Bioekologi Кири-кири. Malang: Universitas Negeri Malang.

Setiawan, R., Retno, W., \& Fatimah,S. (2018). Keanekaragaman Jenis Kupu-Kupu (Lepidoptera:Rhopalocera) Di Zona Rehabilitasi Blok Curah Malang Resort Wonoasri Taman Nasional Meru Betiri. Natural Science: Journal of Science and Technology. 7 (2), 252-258. 